\title{
Bilateral breast swelling secondary to superior vena cava obstruction and subclavian vein thrombosis *
}

\author{
Edema bilateral das mamas secundário a obstrução da veia cava superior e trombose de veia subclávia \\ Ariadne Mayumi Yamada ${ }^{1}$, Ana Lucia Kefalas Oliveira Melo ${ }^{2}$, Gesner Pereira Lopes ${ }^{3}$, Genesio Borges \\ de Andrade Neto $^{1}$, Valesca Bizinoto Monteiro ${ }^{1}$, Renato Santos Soares ${ }^{1}$
}

\begin{abstract}
Superior vena cava syndrome is defined by a set of signs and symptoms secondary to superior vena cava obstruction caused principally by malignant diseases. The present report describes the case of an unusual clinical manifestation of this syndrome with bilateral breast swelling, and emphasizes the relevance of knowledge on mammographic signs of systemic diseases.
\end{abstract}

Keywords: Mammography; Superior vena cava syndrome; Subclavian vein thrombosis.

Resumo A síndrome da veia cava superior é definida por um conjunto de sinais e sintomas secundários a uma obstrução da veia cava superior, causada principalmente por neoplasias malignas. Este relato de caso demonstra uma manifestação clínica incomum dessa síndrome, o edema bilateral das mamas, e destaca a importância do conhecimento dos sinais mamográficos de doenças sistêmicas.

Unitermos: Mamografia; Síndrome da veia cava superior; Trombose de veia subclávia.

Yamada AM, Melo ALKO, Lopes GP, Andrade Neto GB, Monteiro VB, Soares RS. Bilateral breast swelling secondary to superior vena cava obstruction and subclavian vein thrombosis. Radiol Bras. 2013 Jul/Ago;46(4):252-254.

\section{INTRODUCTION}

Superior vena cava syndrome is defined by a set of signs and symptoms secondary to superior vena cava obstruction. Such a syndrome was first described in 1757 by William Hunter, in a patient with syphilitic aortic aneurysm ${ }^{(\mathbf{1})}$. Currently, malignant diseases represent the main etiologic factors associated with this syndrome. Thrombotic conditions also constitute frequent causes, reflecting an increase in the utilization of intravascular catheters. Most common clinical manifestations include facial and upper limbs swelling, presence of collateral circulation in the neck and chest,

* Study developed at Universidade Federal do Triângulo Mineiro (UFTM), Uberaba, MG, Brazil.

1. MDs, Residents in Radiology and Imaging Diagnosis, Universidade Federal do Triângulo Mineiro (UFTM), Uberaba, MG, Brazil.

2. PhD, Titular Member of Colégio Brasileiro de Radiologia e Diagnóstico por Imagem CBR), Associate Professor, Universidade Federal do Triângulo Mineiro (UFTM), Uberaba, MG, Brazil.

3. Master, Titular Member of Colégio Brasileiro de Radiologia e Diagnóstico por Imagem (CBR), Head of Division of Radiology and Imaging Diagnosis, Universidade Federal do Triângulo Mineiro (UFTM), Uberaba, MG, Brazil.

Mailing Address: Dra. Ariadne Mayumi Yamada. Avenida Leopoldino de Oliveira, 579, Bloco 23, ap. 103, Parque do Mirante. Uberaba, MG, Brazil, 38081-000.E-mail: kenkoyamada@ hotmail.com.

Received November 1st, 2012. Accepted after revision March 7, 2013. facial plethora, visual symptoms, dyspnea and $\operatorname{cough}^{(2)}$. The breast swelling described in the present case report is an uncommon manifestation.

\section{CASE REPORT}

A 38-year-old female patient, smoker, presented with dyspnea and chest pain for nine days, left upper limb edema and bilateral breast swelling for three days. The initial diagnosis was pneumonia. Antibiotic therapy was subsequently initiated. The patient was submitted to bilateral mammography which demonstrated skin and subcutaneous thickening bilaterally, with no evidence of nodules or microcalcifications (Figures 1 and 2). Contrast-enhanced chest computed tomography demonstrated the presence of an ill-defined mediastinal mass causing deviation and invasion, particularly of the superior vena cava (Figure 3). Doppler ultrasonography of upper limbs demonstrated total occlusion of the subclavian, axillary and brachial veins at left, caused by the presence of a thrombus attached to the luminal surface. The patient progressed with facial swelling, anasarca, worsening of her clinical condition and death due to respiratory failure. Anatomopathological analysis revealed the presence of a carcinoma of the upper lobe

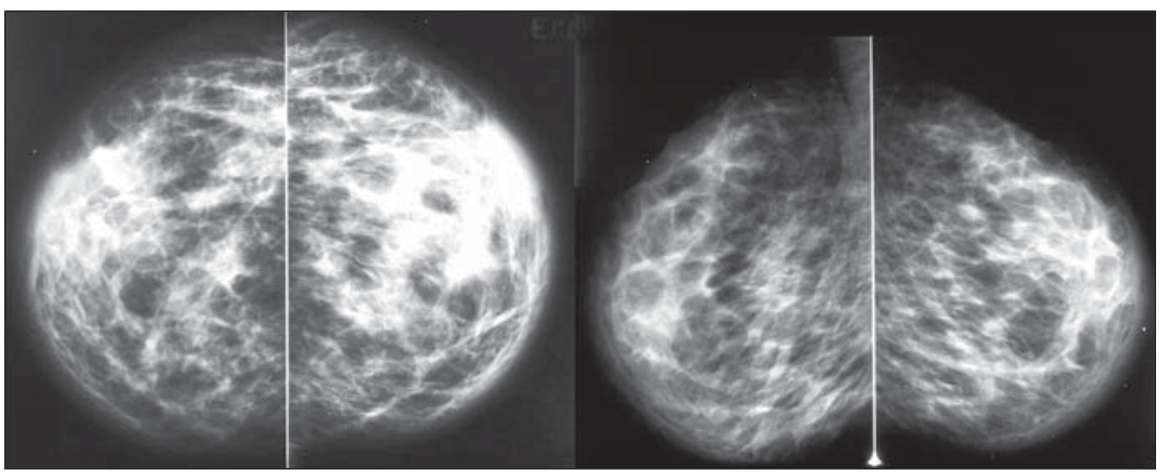

Figure 1. Mammography, bilateral craniocaudal and mediolateral oblique views with parenchymal evaluation technique. Skin and subcutaneous thickening, bilaterally, with no sign of nodules or microcalcifications. 


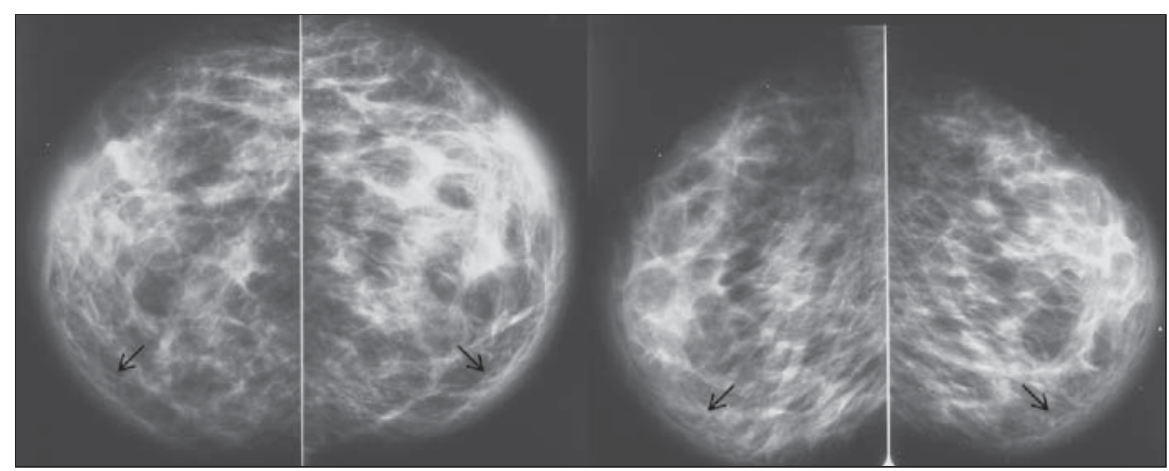

Figure 2. Mammography, bilateral craniocaudal and mediolateral oblique views with skin evaluation technique. Skin and subcutaneous thickening, bilaterally (arrows), with no sign of nodules or microcalcifications. ness of the cranial and lateral skin is $<2.5$ $\mathrm{mm}$; on the other hand, the thickness of the medial and caudal skin may be $>3 \mathrm{~mm}^{(\mathbf{1 4})}$. In the present case, bilateral breast swelling represented by skin thickening was observed. The deep venous drainage of the breast occurs through the internal mammary and axillary veins, which drain into the pulmonary capillary vasculature, and intercostals veins, which drain into the superior vena cava and lungs (Figure 4$)^{(\mathbf{1 5}, \mathbf{1 6})}$. The anatomical site of the subclavian occlusion will determine if the clinical condition will be marked either by upper limb

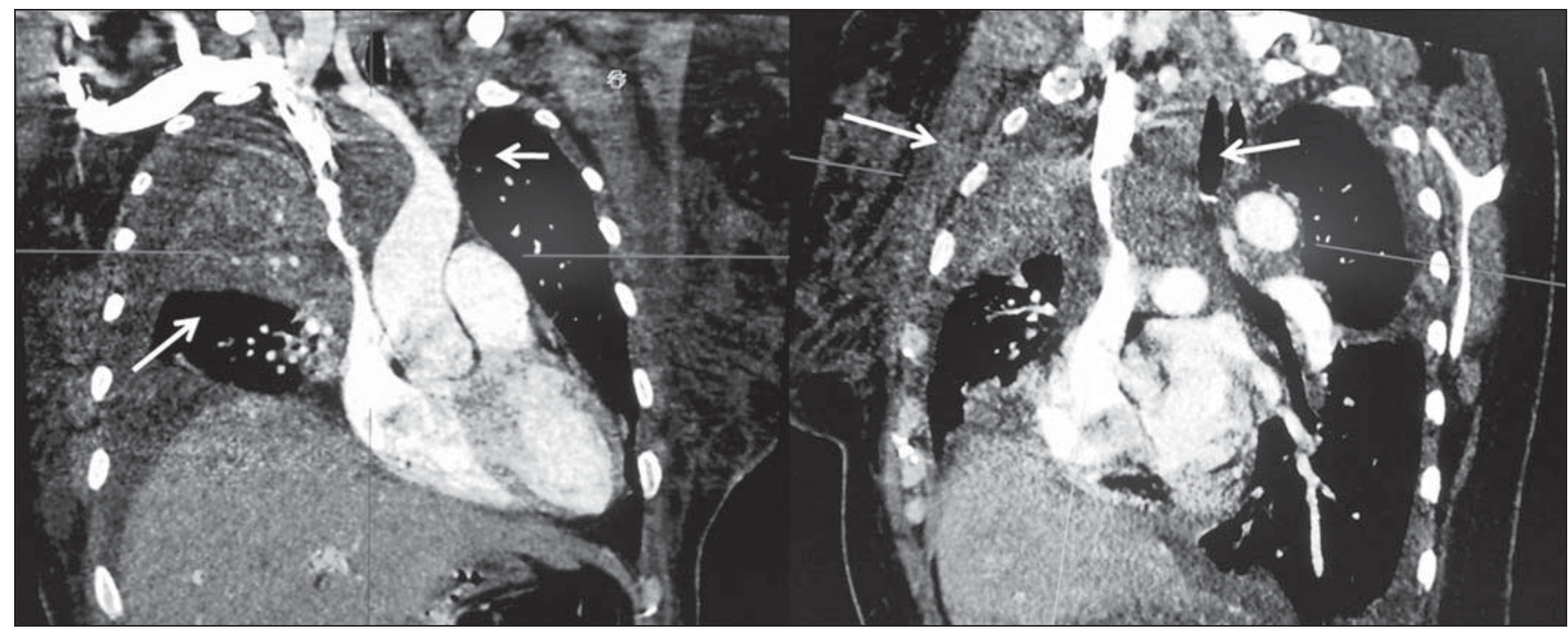

Figure 3. Contrast-enhanced chest computed tomography, coronal and sagittal sections. III-defined mediastinal mass with invasion of the superior vena cava (arrows).

of the left lung, left subclavian vein thrombosis, and metastases to the liver, kidneys and small bowel.

\section{DISCUSSION}

The Brazilian radiological literature has recently reflected a great preoccupation with the role played by imaging methods in the improvement of breast diseases diagnosis $^{(3-12)}$. Although mammography is utilized mainly for detecting breast cancer, it can also reveal vascular, lymphatic, skin or parenchymal abnormalities related to extramammary diseases ${ }^{(\mathbf{1 3})}$. Skin thickening generally occurs due to increased dermal thickness resulting from edema, collagen accumulation or tumor infiltration. On craniocaudal and mediolateral oblique mammographic views, the normal thick-

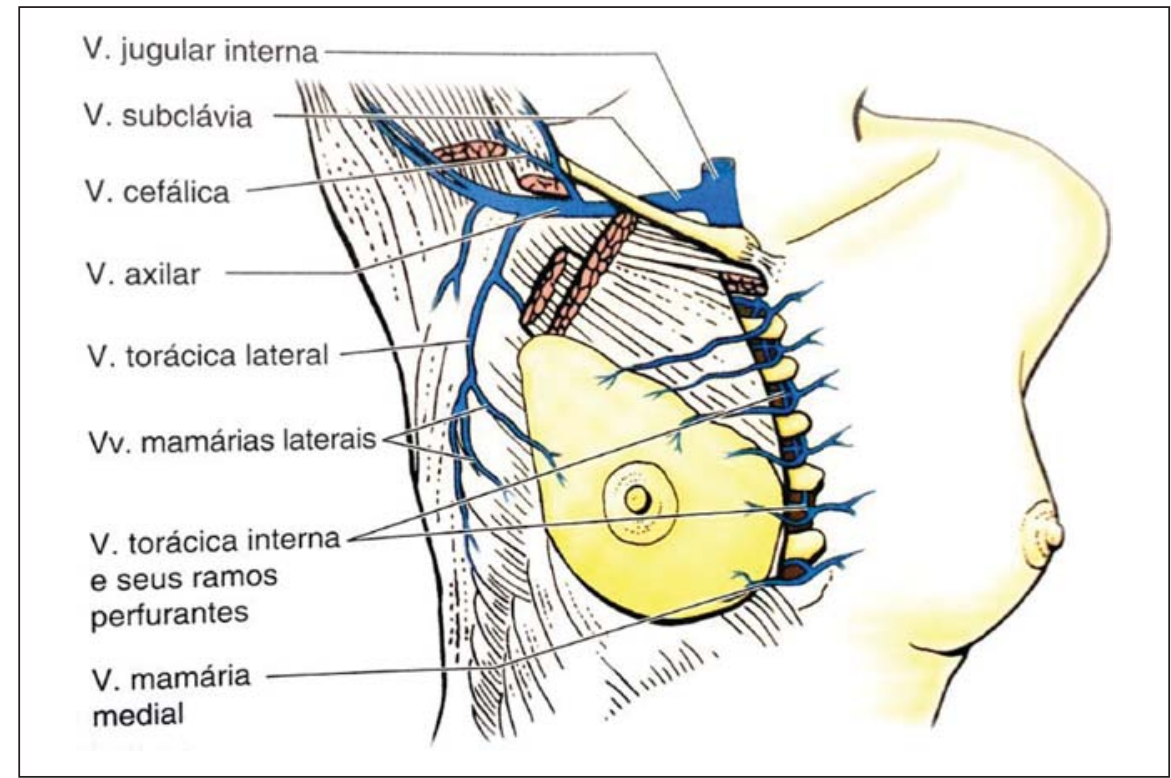

Figure 4. Breast anatomy. The venous drainage is highlighted. 
edema (the most common manifestation), or by breast swelling characterized by the presence stenosis proximal to the junction between the mammary and subclavian veins $^{(\mathbf{1 7})}$. In the present case report the association of the extrinsic compression of the superior vena cava by a lung carcinoma with thrombosis of other central vessels such as the subclavian vein contributed to an increase in the venous pressure and fluid extravasation into the interstitial space, resulting in a bilateral presentation of breast congestion. Breast swelling related to central vessels stenosis has been scarcely reported in the literature, most of times in patients with arteriovenous fistula ${ }^{(\mathbf{1 8})}$. In the present case report, the authors evaluated the relevance of breast skin edema for determining the causes of venous obstruction.

\section{REFERENCES}

1. Parish JM, Marschke RF Jr, Dines DE, et al. Etiologic considerations in superior vena cava syndrome. Mayo Clin Proc. 1981;56:407-13.

2. Lepper PM, Ott SR, Hoppe H, et al. Superior vena cava syndrome in thoracic malignancies. Respir Care. 2011;56:653-66.

3. Miranda CMNR, Santos CJJ, Maranhão CPM, et al. A tomografia computadorizada multislice é ferramenta importante para o estadiamento e seguimento do câncer de mama? Radiol Bras. 2012;45:105-12.

4. Calas MJG, Gutfilen B, Pereira WCA. CAD e mamografia: por que usar esta ferramenta? Radiol Bras. 2012;45:46-52.

5. Azevedo AC, Canella EO, Djahjah MCR, et al. Conduta das funcionárias de um hospital na adesão ao programa de prevenção do câncer de mama. Radiol Bras. 2012;45:215-8.

6. Alvares BR, Freitas CHA, Jales RM, et al. Mammographic density in asymptomatic menopausal women: correlation with clinical and sonographic findings. Radiol Bras. 2012;45:149-54.

7. Barra FR, Barra RR, Barra Sobrinho A. Novos métodos funcionais na avaliação de lesões mamárias. Radiol Bras. 2012;45:340-4.

8. Criado DAB, Braojos FDC, Torres US, et al. Aesthetic breast augmentation with hyaluronic acid imaging findings and implications for radiological assessment. Radiol Bras. 2012;45:181-3.

9. Urban LABD, Schaefer MB, Duarte DL, et al. Recomendações do Colégio Brasileiro de Radiologia e Diagnóstico por Imagem, da Sociedade Brasileira de Mastologia e da Federação Brasileira das Associações de Ginecologia e Obstetrícia para rastreamento do câncer de mama por métodos de imagem. Radiol Bras. 2012;45:334-9.

10. Calas MJG, Alvarenga AV, Gutfilen B, et al. Avaliação de parâmetros morfométricos calculados a partir do contorno de lesões de mama em ultrassonografias na distinção das categorias do sistema BI-RADS. Radiol Bras. 2011;44:289-96.
11. Marques EF, Medeiros MLL, Souza JA, et al. Indicações de ressonância magnética das mamas em um centro de referência em oncologia. Radiol Bras. 2011;44:363-6.

12. Lykawka R, Biasi P, Guerini CR, et al. Avaliação dos diferentes métodos de medida de força de compressão em três equipamentos mamográficos diferentes. Radiol Bras. 2011;44:172-6.

13. Cao MM, Hoyt AC, Bassett LW. Mammographic signs of systemic disease. Radiographics. 2011 31:1085-111.

14. Silva AO, Oliveira ALK, Macedo ACS, et al. Estudo por imagem das patologias mamárias com espessamento de pele: ensaio pictórico. Radiol Bras. 2008;41 Supl 1:11.

15. Bauab S. Anatomia, histologia e fisiologia da mama feminina relacionadas com os aspectos de imagem. In: Aguillar V, Bauab S, Maranhão N. Mama - diagnóstico por imagem. $1^{\mathrm{a}}$ ed. Rio de Janeiro, RJ: Revinter; 2009. p. 8-9.

16. Moore KL. Mama. In: Moore KL, Dalley AF, Agur AMR. Anatomia orientada para a clínica. $6^{\mathrm{a}}$ ed. Rio de Janeiro, RJ: Guanabara Koogan; 2011. p. 100

17. Gadallah MF, el-Shahawy MA, Campese VM. Unilateral breast enlargement secondary to hemodialysis arteriovenous fistula and subclavian vein occlusion. Nephron. 1993;63:351-3.

18. Goo DE, Kim YJ, Choi DL, et al. Bilateral breast enlargement: an unusual presentation of superior vena cava obstruction in a hemodialysis patient with fibrosing mediastinitis. Cardiovasc Intervent Radiol. 2011;34 Suppl 2:S195-7. 